\title{
Corrigendum: Single-Cell RNA Analysis of Type I Spiral Ganglion Neurons Reveals a Lmx1a Population in the Cochlea
}

\author{
Fiorella Carla Grandi ${ }^{1}$, Lara De Tomasi ${ }^{2}$ and Mirna Mustapha ${ }^{2,3 *}$ \\ ${ }^{1}$ Cancer Biology Program, Stanford University, Stanford, CA, United States, ${ }^{2}$ Department of Biomedical Science, University \\ of Sheffield, Sheffield, United Kingdom, ${ }^{3}$ Department of Otolaryngology-Head and Neck Surgery, Stanford University School \\ of Medicine, Stanford, CA, United States
}

Keywords: type I spiral ganglion neurons, single-cell transcriptome, Lmx1a, development, cochlea

\section{A Corrigendum on}

OPEN ACCESS

Approved by:

Frontiers Editorial Office,

Frontiers Media SA, Switzerland

*Correspondence:

Mirna Mustapha

mirna.m@sheffield.ac.uk

Specialty section:

This article was submitted to Molecular Neuroscience Archive,

a section of the journal

Frontiers in Molecular Neuroscience

Received: 27 March 2021 Accepted: 01 April 2021

Published: 05 May 2021

Citation:

Grandi FC, De Tomasi L and Mustapha M (2021) Corrigendum: Single-Cell RNA Analysis of Type I Spiral Ganglion Neurons Reveals a Lmx1a Population in the Cochlea. Front. Mol. Neurosci. 14:686790. doi: 10.3389/fnmol.2021.686790
Single-Cell RNA Analysis of Type I Spiral Ganglion Neurons Reveals a Lmx1a Population in the Cochlea

by Grandi, F. C., De Tomasi, L., and Mustapha, M. (2020). Front. Mol. Neurosci. 13:83. doi: $10.3389 /$ fnmol.2020.00083

In the original article, there was an error. Dr. Gopal Pramanik was acknowledged without his agreement. As per his request, we are removing his name and contribution from the acknowledgment paragraph.

A correction has been made to the Acknowledgments. The corrected paragraph is shown below.

"We sincerely thank Drs. Stefan Heller and Marta Milo for help with data analysis, and Dr. Walter Marcotti for helpful discussion. We also thank Dr. Kathleen J. Millen for generously providing the Lmxla-cre mice and Dr. Theresa Zwingman for answering the many questions we had concerning these mice (Seattle Children's Research Institute Center for Integrative Brain Research, The University of Washington). We thank Dr. Joseph P. Sarsero (Murdoch Children's Research Institute, Australia) for sharing Peripherin-GFP mice with us and Dr. Lin Gan (Flaum Eye Institute, University of Rochester School of Medicine) for sharing Bhlhb5-cre line.”

The authors apologize for this error and state that this does not change the scientific conclusions of the article in any way. The original article has been updated.

Copyright () 2021 Grandi, De Tomasi and Mustapha. This is an open-access article distributed under the terms of the Creative Commons Attribution License (CC BY). The use, distribution or reproduction in other forums is permitted, provided the original author(s) and the copyright owner(s) are credited and that the original publication in this journal is cited, in accordance with accepted academic practice. No use, distribution or reproduction is permitted which does not comply with these terms. 